\title{
PENDAMPINGAN DAN PEMBUATAN VIDEO PROFILE UNTUK PROMOSI WISATA DESA CISANTANA KABUPATEN KUNINGAN
}

\author{
Sigit Setya Kusuma ${ }^{1}$, Dadang Hamdani ${ }^{2}$, Dadan Nugraha ${ }^{3}$, \\ Yati Nurhayati ${ }^{4}$ dan Resma Fahmi Ramdhan ${ }^{5}$ \\ Program Studi Desain Komunikasi Visual S1 1,5, Teknik Informatika S1 ${ }^{2,4}$, Sistem Informasi $\mathrm{S1}^{3}$, \\ Fakultas Ilmu Komputer, Universitas Kuningan, Indonesia \\ E-mail : sigit@uniku.ac.id
}

\begin{abstract}
Cisantana Village is located in the Cigugur sub-district, Kuningan Regency, West Java Province. Cisantana has abundant natural resources because of its geographical location on the slopes of Mount Ciremai. In addition to agricultural potential, Cisantana is also famous for cattle farming. Cisantana Village is a village that has very potential tourism potential. Village Cisantana is blessed with a lot of charm, a charm that must be explored and visualized through record media so that Cisantana Village has an audio visual or can be called a video profile for tourism appeal to the community or tourists.

Keywords: Cisantana Village, Video, Profile, Promotion, Travel
\end{abstract}

\begin{abstract}
Abstrak
Desa Cisantana terletak di kecamatan Cigugur, Kabupaten Kuningan, Provinsi Jawa Barat. Cisantana memiliki sumber daya alam yang melimpah karena letak geografisnya yang berada di lereng gunung Ciremai, Selain potensi pertanian, Cisantana juga terkenal dengan peternakan sapi. Desa Cisantana merupakan desa yang mem-iliki potensi wisata yang sangat potensial. Cisantana desa yang dikarunia banyak pesona, pesona yang harus banyak di eksplorasi dan di visualkan melalui media rekam sehingga Desa Cisantana mempu-nyai sebuah audio visual atau bisa di sebut video profile untuk daya tarik pariwisata terhadap masyarakat atau wisatawan.
\end{abstract}

Kata Kunci : Desa Cisantana, Video, Profile, Promosi, Wisata

\section{PENDAHULUAN}

Peraturan Pemerintah Nomor 43 Tahun 2014 tentang Peraturan Pelaksanaan Undang-Undang Nomor 6 Tahun 2014 Pasal 1, Desa adalah Desa dan Desa adat atau yang disebut dengan nama lain, selanjutnya disebut Desa, adalah kesatuan masyarakat hukum yang memiliki batas wilayah yang berwenang untuk mengatur dan mengurus urusan pemerintahan, kepentingan masyarakat setempat berdasarkan prakarsa masyarakat, hak asal-usul, dan/atau hak tradisional yang diakui dan dihormati dalam sistem pemerintahan Negara Kesatuan Republik Indonesia. Desa merupakan salah satu roda penggerak pemerintahan terkecil tetapi memiliki peranan besar karena berhubungan langsung dengan masyarakat (Yati Nurhayati dan Fauziah, 2019). Salah satu desa di Kabupaten Kuningan yang memiliki potensi Sumber Daya Alam untuk dikembangkan adalah Desa Cisantana. Desa Cisantana terletak di bawah kaki gunung Ciremai yang berada di Kecamatan Cigugur, Kabupaten Kuningan, Provinsi Jawa Barat. Cisantana merupakan salah satu desa penghasil sayuran, ternak dan juga desa wisata di wilayah kecamatan Cigugur, kabupaten Kuningan. Cisantana termasuk desa yang berada di kawasan dataran tinggi yaitu 750-1.200 mdpl. Iklim curah hu-jannya $3.500 \mathrm{~mm} / \mathrm{tahun}$. Jumlah bulan hujan 3-6 bulan dan suhu rata-rata hari-an 22-26 c. Nama Cisantana diambil dari bahasa pewayangan, yakni, dari kata "Cis" dan "Santana". Cis adalah keris, 
sedangkan Santana adalah menak/elit. Jadi kalau digabungkan Cisantana adalah keris milik orang elit. Keris mel-ambangkan pemberani, dan elit menunjukkan orang-orang Cisantana ini ber-wibawa, berpendidikan (Pardiman, 1 agustus 2019). Desa Cisantana memiliki potensi wisata yang sangat bagus untuk di eksplorasi, potensi-potensi wisata yang baru muncul dapat di eksplorasi melalui pembuatan video profile. Wisata yang ada di Desa Cisantana 70\% di kelola Oleh BUMDES Desa Cisantana. Cisantana merupakan desa yang potensi Sumber Daya Alamnya yang melim-pah, kekayaan alam desa Cisantan cukup banyak seperti Sumber Mata Air, Per-tanian, Peternakan dan Pesona Desa Cisantan.

1. Sumber Mata Air

Air yang digunakan masyarakat Cisantana berasal dari mata air gunung yang bermuara di beberapa mata air. Ada yang mengambil dari mata air Cibunian, yang bertempat di kawasan Bumi Perkemahan (Buper) dan ada juga mata air dari Depok, serta dari mata air Makulisi. Khusus untuk warga Ciputri sumber airnya dari mata air Ciputri. Sumber mata air tersebut di-manfaatkan oleh warga, baik untuk kebutuhan sehari-hari maupun untuk pengairan ladang. Perkumpulan Petani Pemakai Air (P3A) Mitra Cai meru-pakan pengelola air yang penggunaannya masih manual, menggunakan pi pa besar dari sumber mata air yang dialirkan ke tuk (tempat penampungan air). Selanjutnya, dari tuk itu, warga menggunakan selang-selang untuk di-alirkan ke rumah mereka.

2. Pertanian

Cisantana memiliki sumber daya alam yang melimpah karena letak geografisnya yang berada di lereng gunung Ciremai sehingga memungkinkan kondisi tanahnya kaya akan unsur hara. Hasil pertanian yang melimpah dari Cisantana terdiri dari bawang daun, padi, tomat, wortel, kol, kentang, kucai dan sawi.

3. Peternakan

Selain potensi pertanian, Cisantana juga terkenal dengan peternakan sapi. Maka tidak mengherankan jika sebagian besar warganya berprofesi se-bagai peternak sapi.

4. Pesona Desa Cisantana

Desa Cisantana memiliki banyak pesona, tetapi wisata yang sudah tidak asing lagi dan banyak dikunjungi yaitu Buper Palutungan dan Goa Maria. Sejak tahun 20162019 Desa Cisantan banyak perubahan dengan banyak-nya pesona wisata yang muncul seperti Sukageri View, Curug Landung, Taman Cisantana dan masing banyak lagi.

Dalam dunia bisnis persaingan telah menjadi suatu hal yang sudah tidak asing lagi dan menjadi tantangan tersendiri bagi pelaku bisnis, baik dari segi kualitas produk, harga yang sesuai, pemasaran dan pelayanan dari perusahaan tersebut (Fina dan Cecep Juliansyah dan Dadan Nugraha, 2019). Salah satu bisnis yang sedang dikembangkan saat ini oleh pemerintah desa untuk meningkatkan pendapatan daerah adalah desa pariwisata.

Menurut Priasukmana \& Mulyadin (2013), Desa Wisata adalah suatu kawasan pedesaan yang menawarkan keseluruhan dari suasana yang mencerminkan keaslian dari pedesaaan itu sendiri mulai dari sosial budaya, adat istiadat, keseharian, memiliki arsitektur bangunan dan struktur tata ruang desa yang khas dan dari kehidupan sosial ekonomi atau kegiatan perekonomian yang unik dan menarik serta mempunyai potensi 
untuk dikembangkanya berbagai komponen kepariwisataan, misalnya atraksi, akomodasi, makanan-minuman, cinderamata, dan kebutuhan wisata lainnya.

Menurut Yoeti Oka (2013), perencanaan dalam membangun desa wisata yang baik harus memiliki aspek : tersedianya fasilitas transportasi, daya tarik objek wisata, fasilitas dan pelayanan, Informasi dan promosi. Menurut Anton Tejakusuma ( dalam Mega Super Salesman, 2010 ) promosi merupakan sebuah tindakan yang bertujuan untuk meningkatkan penjualan, juga sebagai strategi untuk mengajak prospek melalui transaksi.

Cisantana desa yang dikarunia banyak pesona, pesona yang harus banyak di eksplorasi dan di visualkan melalui media rekam sehingga Desa Cisantana mempunyai sebuah audio visual atau bisa di sebut video profile untuk daya tarik terhadap masyarakat yang belum pernah berkunjung. Tidak banyak wisata yang sangat bagus di pedesaan kabupaten memiliki sebuah rekaman pesonanya. Kuningan menjadi potensi banyak desadesa wisata alam seperti Desa Cisantana yang perlu dipromosikan dan direkam dengan menarik. Video adalah teknologi untuk menangkap, merekam, memproses, mentransmisikan dan menata ulang citra bergerak. Teknologi ini biasanya menggunakan film seluloid, sinyal elektronik, atau media digital. Video juga dapat diartikan sebagai gabungan citra - citra mati yang dibaca berurutan dalam suatu waktu dengan kecepatan tertentu. Citra - citra mati tersebut dinamakan frame dan kecepatan pembacaan gabungan citra disebut dengan frame rate, dengan satuan fps (frame per second) (Hashlinda et al. 2012). Pesatnya perkembangan teknologi informasi saat ini membuat manusia semakin memerlukan komputer dalam berbagai aktivitasnya. Keperluan tersebut mencakup berbagai aspek kebutuhan baik perorangan maupun instansi dan juga merambah ke berbagai bidang, seperti pendidikan, kesehatan, ekonomi, komunikasi, bisnis, hiburan dan lainnya (Jajang, Dadang Hamdani dan Panji Novantara, 2018). Berdasarkan kondisi diatas maka dibuatlah sebuah Program Pengabdi-an Kepada Masyarakat dengan judul "Pendampingan Dan Pembuatan Video Profile Wisata Desa Cisantana Sebagai Salah Satu Promosi Wisata Di Kabupaten Kuningan".

\section{METODE PELAKSANAAN}

Kegiatan PkM ini akan dilaksanakan dalam bentuk penerapan kepada perangkat desa yang ada di Desa Cisantana Kecamatan Cigugur, Kabupaten Kuningan. Adapun tahapan-tahapan proses yang akan dilaksanakan adalah se-bagai berikut.

1. Tahap Persiapan

a) Melakukan survey lokasi kegiatan

b) Pemantapan serta penetuan lokasi dan sasaran

c) Menyusun agenda kegiatan

d) Menyusun konsep video profile

2. Metode Pelaksanaan dalam Proses Pembuatan Video Profile

Tahap pelaksanaan kegiatan dilakukan secara terstruktur mengacu pada jadwal acara yang telah dibuat sebelumnya.

a) Pra Produksi/Pre-Production

Tahap awal atau persiapan video profile adalah dengan menacari refer-ensi video profile yang sudah ada, memproses materi outline yang berisi shooting objective, durasi, target audience, tempat/setting, budget dan lain lain. Setelah semua 
bahan-bahan materi outline terkumpul dan terseleksi, scripwriter akan mengolah bahan tersebut menjadi naskah video profile. Di dalam naskah video profile umumnya terdapat narasi naskah berupa penjelasan audio, video dan keterangan scene yang membentuk alur cerita video profile.

Dalam tahap pembuatan materi outline dilakukan diskusi dengan perangkat desa menggunakan metode elaborasi atropologi kognitif.. Elaborasi Antropologi kognitif adalah manifestasi dalam bentuk lisan, visual, tulisan, dan aturan yang ada di masyarakat dalam bentuk fenomena budaya, agama, masyarakat, dan politik di masyarakat Nusantara (Jerry Dounald Rahajaan dan Sigit Setya Kusuma, 2018)

b) Produksi/Production

Merupakan tahap pelaksanaan di mana shooting video profile dil-akukan. semua hasil shooting merujuk pada naskah storyboard yang sudah dibuat ditahap pra produksi atau persiapan. Pada tahap produksi ini, team akan mengambil gambar video sesuai dengan naskah video profile. Pengambilan gambar pada shooting video profile tidak harus sesuai urutan scene biasanya diacak berdasarkan pada hal-hal termudah untuk di shooting.

Faktor-faktor yang menjadi bahan pertimbangan dalam pengambilan gambar video profile kurang lebih adalah lokasi dan avabilitas orang-orang bersangkutan. Lokasi yang jauh akan memerlukan waktu lebih untuk ketempat tujuan dan diperlukan survey sebagai upaya menyesuaikan lokasi setempat dengan naskah video profile.

Pada tahap produksi ini, penting untuk mengambil stock gambar lebih banyak sebagai upaya preventif dalam kekurangan stock shoot gambar. Karena pengulangan akan memakan biaya produksi, waktu dan tenaga

c) Pasca Produksi

Merupakan tahap akhir atau penyempurnaan dalam memproses hasil shooting untuk diedit/diolah. Pengolahan atau editing yang dilakukan meliputi aspek suara, gambar dan alur cerita sesuai naskah video profile wisata. Secara terperinci tahap pasca produksi adalah sebagai berikut.

Editing offline - voice over - music development (scoring) - audio mixing online editing.

1) Proses pertama dalam pasca produksi video profile adalah editing offline. Dalam proses ini hasil gambar di captured/di pindahkan dari media ka-mera lalu diproses melalui komputer. Pada tahap selanjutnya proses seleksi editing offline dilakukan dengan mencari scene dari take gambar yang bagus un-tuk di urut sesuai naskah video profile.

2) Proses kedua adalah voice over, memasukan instrumen audio ke dalam video profile untuk mengisi keterangan gambar dan sebagai narrator untuk penjelasan-penjelasan pesan yang ingin disampaikan. Dalam voice over terbagi atas dua pengisi MVo atau male voice over diisi dengan audio lakilaki dan FVo atau female voice over yang diisi dengan audio perempuan.

3) Proses ketiga dalam pasca produksi adalah adalah music development/scoring. Scoring adalah instrumen audio pelengkap sebagai musik latar yang menghiasi tampilan video company profile. Scoring dapat 
diisi dengan ull musik (lagu) atau instrumen musik (tanpa suara). Untuk memilih scoring musik pada video profile diharuskan untuk memperhatikan hak cipta musik yang dipilih. Karena dalam pembuatan scoring menggunakan full musik harus membayar royalty kepada pencipta dan penyanyi musik tersebut. Sedangkan untuk scoring instrumen lebih kepada kreasi editor.

4) Proses keempat adalah audio mixing, merupakan proses penggabungan audio langsung dari video captured, audio voice over dan audio scoring. Pada tahap ini editor akan memastikan keterangan audio tepat pada scene-scene yang telah dibuat pada naskah video profile.

5) Proses kelima adalah editing online, merupakan tahap editing terakhir yang melengkapi penyempurnaan dari proses pasca produksi mulai dari proses editing offline, voice over, audioscoring dan audio mixing. Pada tahap ini editor meracik semua komponen yang telah diproses untuk dijadikan video profile yang utuh. Di proses terakhir ini pula elemen grafis ditambahkan untuk memoles video profile agar hasil maksimal pesan tersampaikan.

Dalam proses produksi sebuah video profie, persiapan matang merupa-kan faktor penting dalam produksi. Demikian tahapan-tahapan pada proses produksi, semoga dengan pengetahuan dan proses yang terperinci mengenai pembuatan video profile dapat membantu dan memperjelas langkah-langkah yang akan dilakukan

\section{HASIL DAN PEMBAHASAN}

Adapun hasil dari program pengabdian kepada masyarakat ini adalah :

1. Pra Produksi/Pre-Production yaitu Diperoleh referensi video dimana tarhet audience adalah seluruh masyarakat. Membuat narasi naskah profile.

2. Produksi/Production yaitu Dilakukan pengambilan gambar sesuai naskah/skenario yang telah dibuat.

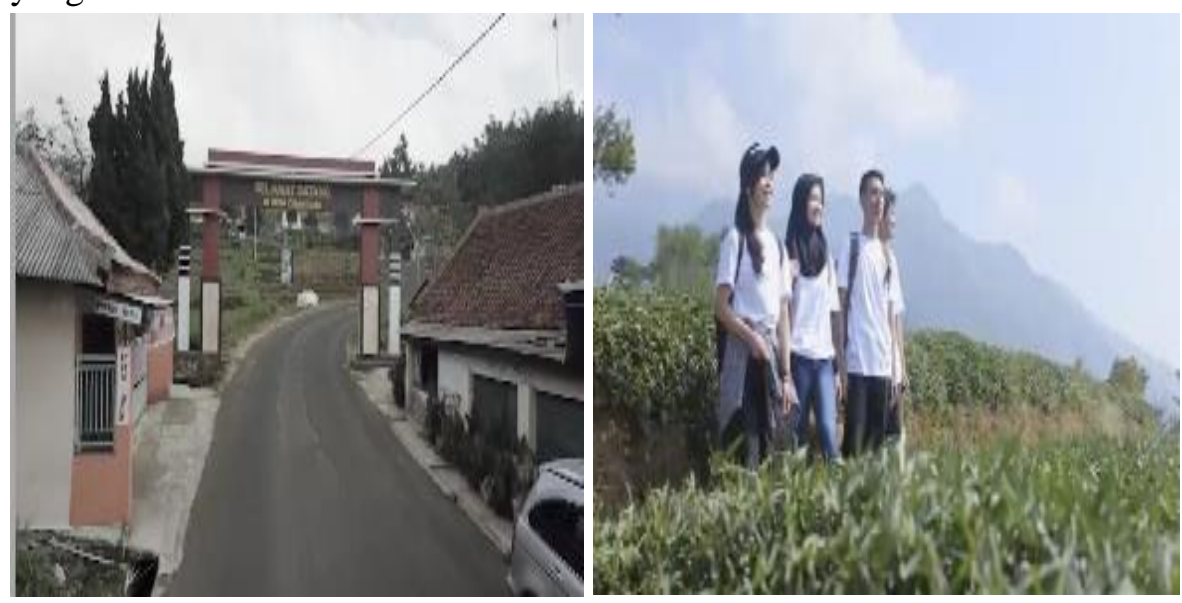


Empowerment : Jurnal Pengabdian Masyarakat, e-ISSN 2598-2052

Vol. 03 Nomor 02.2020.81-88.
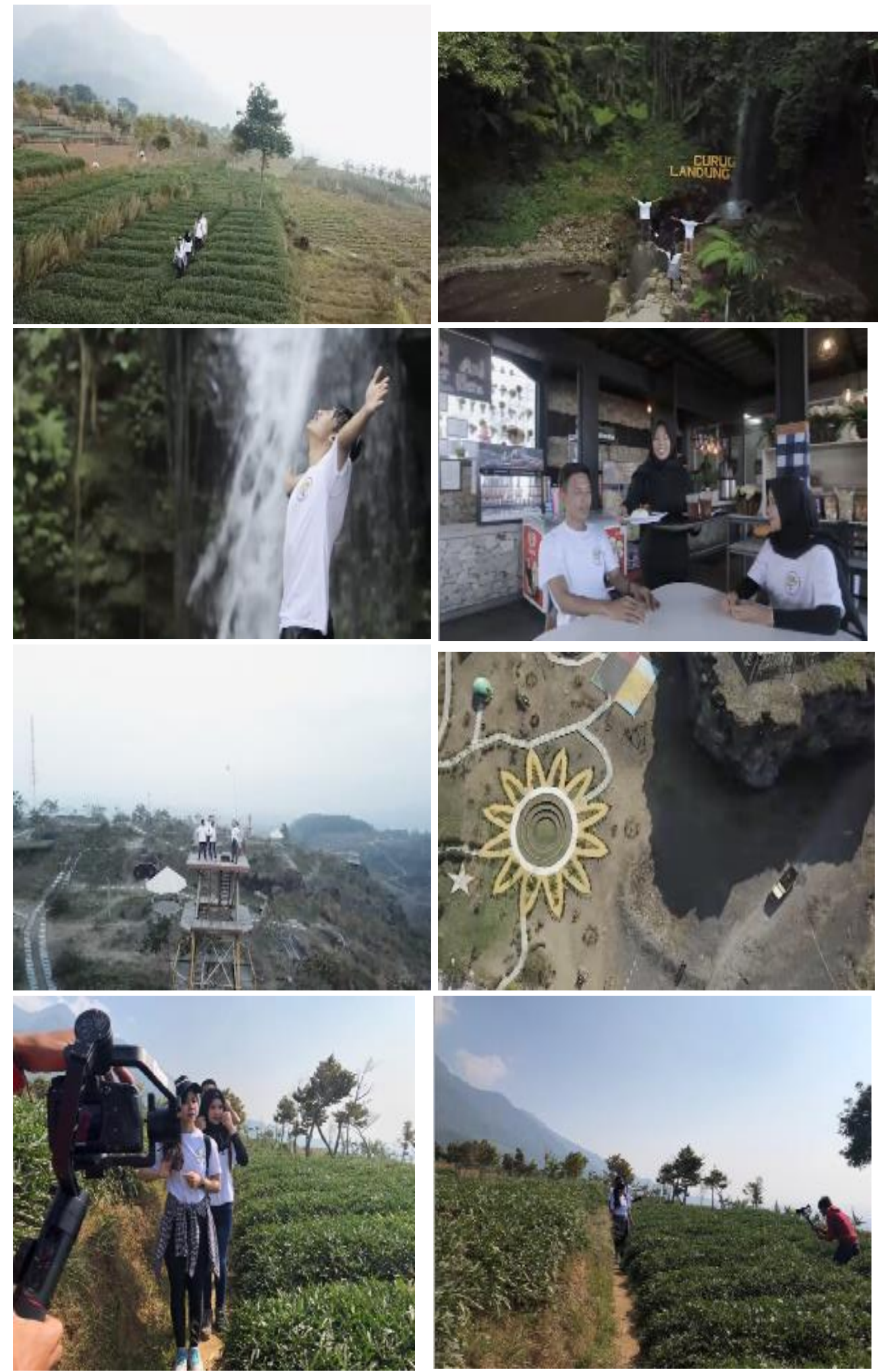

Gambar 1. Kumpulan Pengambilan Gambar Video Profile 
3. Pasca Produksi yaitu Editing dari video yang telah diambil untuk menghasilkan video profile yang sesuai kebutuhan.
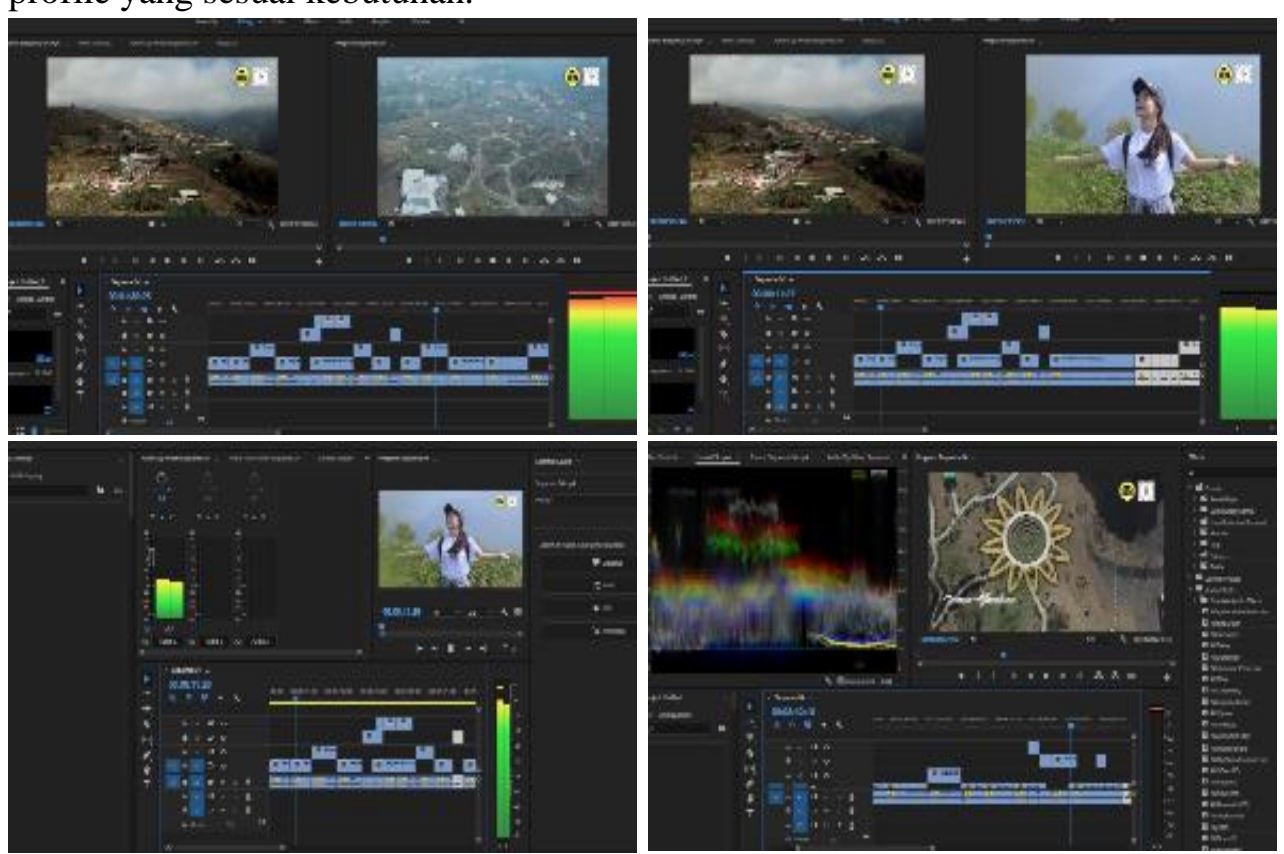

Gambar 2 Proses Editing Video Profile

\section{SIMPULAN}

Berdasarkan uraian tersebut di atas maka penulis disimpulkan beberapa hal berikut yaitu antara lain :

1. Kegiatan Pengabdian Pada Masyarakat berhasil membuat video profile sebagai media promosi bagi Desa Cisantana.

2. Kegiatan telah berhasil memberikan kesadaran terhadap pengurus/pemerintah desa Cibinuang terkait pentingnya promosi Desa Wisata dalam program kerja mereka.

3. Kegiatan pelatihan berhasil mendorong pengurus ataupun pemerintah desa untuk menyusun dan menentukan program kerja yang mungkin untuk dilaksanakan.

4. Kegiatan pelatihan telah memberikan keterampilan membuat pemetaan wilayah dan konsep desain desa wisata

\section{SARAN}

Untuk mengoptimalkan hasil dari kegiatan pengabdian ini, maka disarankan untuk dilakukan program secara intensif dan berkesinambungan dengan melibatkan dinas yang terkait serta asosiasi sehingga kegiatan peningkatan promosi disemua elemen masyarakat dan berbagai bidang.

\section{UCAPAN TERIMA KASIH}

Penulis ucapkan terima kasih kepada semua pihak yang telah membantu terlaksananya kegiatan pengabdian kepada masyarakat ini, diantaranya adalah Rektor Universitas Kuningan, Ketua LPPM Universitas Kuningan, Dekan Fakultas Ilmu Komputer, seluruh jajaran perangkat Desa Cisantana, warga Desa Cisantana. Semoga dengan adanya kegiatan pengabdian kepada masyarakat ini dapat berjalan berkesinambungan dan diterima banyak pihak. 
Empowerment : Jurnal Pengabdian Masyarakat, e-ISSN 2598-2052

Vol. 03 Nomor 02.2020.81-88.

\section{DAFTAR PUSTAKA}

Abdurrahman, Jajang dan Hamdani, Dadang dan Novantara, Panji. 2018. Implementasi Customer Relationship Management (CRM) PadaPenerimaan Siswa Baru(Studi Kasus di Pondok Pesantren DarussalamKabupaten Garut). NUANSA INFORMATIKA : FKOM UNIKU. Vol 12 No 1.

Haslinda, A. And Mukhlash, I.2012.Implementasi Algoritma Block Matching Pada Ekstraksi Objek Bergerak.Institut Teknologi Sepuluh November:Surabaya.

Khasanah, Fina Fathatul dan Abbas, Cecep Juliansyah dan Nugraha, Dadan. 2019. Implementasi Metode Promethee Pada Sistem Pendukung Keputusan Dalam Memberikan Reward Terhadap Customer Pada Aplikasi Bengkel. Cloud Computing : SIS1 FKOM UNIKU. Vol 4 No 2.

Madjadikara Agus S .2008 . Bagaimana Biro Iklan Memproduksi Iklan, Jakarta: PT. Gramedia Pustaka Utama

Nurhayati, Yati dan Fauziah. 2019. Rancang Bangun Sistem Informasi Pemerintahan Desa Untuk Ppeningkatan Ppelayanan Berbasis Web dan Android. Vol 5 No 2. [https://journal.uniku.ac.id/index.php/buffer/article/view/2321/1638 - akses 2019]

Priasukmana Soetarso dan R. Mohamad Mulyadin, 2013, Pembangunan Desa Wisata : Pelaksanaan Undang-undang Otonomi Daerah.

Rahajaan, Jerry Dounald dan Kusuma, Sigit Setya. 2018.The Meaning of Nutmeg and Clove North Maluku In Popular Culture. Balong International Journal of Design : DKV FKOM UNIKU. Vol 1 No 1.

Yoeti Oka, 2013, Perencanaan \& Pengembangan Pariwisata, Penerbit Pratnya Paramita.

Undang-Undang Nomor 6 Tahun 2014 tentang Desa

Peraturan Pemerintah Nomor 43 Tahun 2014 tentang Peraturan Pelaksanaan UndangUndang Nomor 6 Tahun 2014 tentang Desa 